\title{
Топічні назальні кортикостероїди в комплексному лікуванні медикаментозного риніту
}

\section{О.Ю. Меркулов}

Харківська медична академія післядипломної освіти, Харків, Україна

Анотація. Пацієнти з медикаментозним ринітом до звернення до лікаря найчастіше для усунення закладеності носа продовжують застосовувати судинозвужувальні назальні препарати, тим самим посилюючи перебіг захворювання. Мета: дослідити ефективність застосування інтраназальних топічних кортикостероїдів у лікуванні пацієнтів із медикаментозним ринітом. Об'єкт і методи дослідження. Досліджувану групу становили 20 пацієнтів із медикаментозним ринітом, перебіг якого тривав до 2 років. Пацієнтам цієї групи призначено мометазону фуроат у формі інтраназального спрею по 2 дози (100 мкг) у кожен носовий хід 1 раз на добу вранці. Для полегшення носового дихання пацієнти продовжували застосовувати деконгестанти, які розводили 50\% стерильним ізотонічним розчином натрію хлориду через кожні 4 дні. Контрольна група пацієнтів (16 осіб, у яких відмічали медикаментозний риніт протягом не більше 2 років) використовували аналогічний метод розведення деконгестанту, але топічний кортикостероїд не застосовували. Результати. 14 пацієнтів контрольної групи відзначали неефективність застосовуваних деконгестантів вже при 2-му, 2 пацієнти — при 3-му розведенні. В основній групі тільки 2 пацієнти відзначали неефективність при 2-му розведенні, 14 - при 3-му і 4 - стверджували, що після 3-го розведення у них зберігався ефект від деконгестанту, але менш виражений. Висновок. Застосування топічних назальних кортикостероїдів у лікуванні медикаментозного риніту дозволяє суттєво знизити дозу деконгестантів, що застосовуються, або навіть повністю відмовитися від них.

Ключові слова: медикаментозний риніт, назальні вазоконстриктори, деконгестанти, нафазолін, топічні назальні кортикостероїди, мометазону фуроат.

\section{Вступ}

3 проблемою медикаментозного риніту стикається кожен практикуючий оториноларинголог. За даними проведеного нами опитування 36 отоларингологів з різних регіонів України, їх пацієнти з медикаментозним ринітом до звернення до лікаря найчастіше для усунення закладеності носа продовжували застосовувати судинозвужувальні назальні препарати, тим самим посилюючи перебіг захворювання.

Основною групою сучасних судинозвужувальних назальних засобів (деконгестантів) $\epsilon$ похідні імідазоліну. Перший представник цієї групи, нафазолін, синтезований наприкінці 1930-х років німецьким хіміком Адольфом Зонном (Adolf Sohn). Нафазолін - вазоконстриктор короткої дії (судинозвужувальний ефект триває 4-6 год), що має суттєві обмеження щодо застосування у дітей та осіб похилого віку. Через деякий час після початку клінічного застосування нафазоліну з'явилися повідомлення про небажані побічні ефекти цього препарату (розвиток так званої нафазолінової залежності) [1, 2]. У період 1955-1961 рр. синтезовані інші похідні імідазоліну: тетризолін, ксилометазолін, оксиметазолін. Ці препарати відрізнялися більш тривалою вазоконстрикторною дією. Так, тривалість судинозвужувального ефекту ксилометазоліну становить 6-8 год, оксиметазоліну - до 10-12 год. Сьогодні ці два пре- парати займають основну частку світового ринку назальних деконгестантів.

Для практикуючих лікарів важливо знати, які деконгестанти в яких вікових групах та в якій дозі можна застосовувати. У таблиці наведено основні назальні вазоконстриктори (діючі речовини), що застосовують з лікувальною метою у пацієнтів різних вікових груп.

Що стосується тривалості застосування назальних вазоконстрикторів, то первинна рекомендація для оксиметазоліну гідрохлориду у формі спрею становила 3 дні. У ряді досліджень показано відносну безпеку застосування оксиметазоліну протягом 5 днів. Препарати нафазоліну у дітей не можна застосовувати $>3$ днів, у дорослих $->5$ днів. Тривале (>10 днів) застосування топічних судинозвужувальних препаратів викликає назальну гіперреактивність, а на пізніших етапах - зміни гістологічної будови слизової оболонки та розвиток медикаментозного риніту. Медикаментозний риніт, що розвивається в результаті тривалого, часто неконтрольованого застосування деконгестантів, зумовлює характерні гістологічні зміни в слизовій оболонці порожнини носа. Це відрізняє його від носової обструкції, викликаної прийомом пероральних лікарських препаратів, таких як блокатори $\beta$-адренорецепторів, антипсихотичні засоби, антигіпертензивні засоби, пероральні контрацептиви. Ряд досліджень

Таблиця Можливості застосування деконгестантів у пацієнтів різних вікових груп

\begin{tabular}{|c|c|c|c|c|c|c|c|}
\hline \multirow{2}{*}{ Назальний вазоконстриктор } & \multicolumn{7}{|c|}{ Вік пацієнта } \\
\hline & 0-4 тиж & 1-6 мiс & 6 міс-1 рік & 1-2 роки & 2-6 років & 6-12 років & $>12$ років \\
\hline \multicolumn{8}{|l|}{ Оксиметазоліну гідрохлорид 0,01\% } \\
\hline \multicolumn{8}{|l|}{ Оксиметазоліну гідрохлорид 0,025\% } \\
\hline \multicolumn{8}{|l|}{ Оксиметазоліну гідрохлорид 0,05\% } \\
\hline \multicolumn{8}{|l|}{ Ксилометазоліну гідрохлорид 0,05\% } \\
\hline \multicolumn{8}{|l|}{ Фенілефрину гідрохлорид 2,5 мг/мл } \\
\hline \multicolumn{8}{|l|}{ Трамазоліну гідрохлорид 1,18 мг/мл } \\
\hline Нафазолін 0,05\% & & & & & & 3-15 років & \\
\hline Нафазолін 0,1\% & & & & & & & $>15$ років \\
\hline
\end{tabular}


вказує, що розвиток подібних гістологічних змін слизової оболонки носа може бути пов'язаний з циліотоксичним ефектом (пошкодження війок миготливого епітелію слизової оболонки носа) бензалконію хлориду - консерванта-антисептика, який входить до складу більшості назальних судинозвужувальних препаратів [3-4]. Поєднання бензалконію хлориду та динатрію едетату, яке $\epsilon$ у складі допоміжних речовин більшості назальних крапель та спреїв, при тривалому застосуванні викликає розвиток запалення, що супроводжується еозинофільною інфільтрацією слизової оболонки та атрофією епітелію. Негативний вплив цих речовин на слизову оболонку підтверджує і той факт, що вони не використовуються у складі судинозвужувальних назальних крапель та спреїв, розроблених для пацієнтів із «чутливою» слизовою оболонкою.

У процесі комплексного лікування медикаментозного риніту відмова пацієнта від застосування назальних вазоконстрикторів $\epsilon$ основним завданням. Метод поступового зниження концентрації діючої речовини шляхом повторних розведень давно застосовується в медицині для вирішення проблеми медикаментозної залежності. У випадку медикаментозного риніту розведення назального судинозвужувального препарату стерильним ізотонічним розчином натрію хлориду призводило би до зниження концентрації не тільки самого вазоконстриктора, але й допоміжних речовин, що становлять для нас інтерес.

Слід зазначити, що вміст бензалконію хлориду в назальних судинозвужувальних краплях і спреях досягає 0,2 мг/мл, а динатрію едетату - 0,5 мг/мл. У нашій практиці поступового зниження концентрації деконгестанту в назальних спреях і краплях ми спостерігали, що пацієнти з медикаментозним ринітом відзначали їх низьку ефективність вже при 3-разовому розведенні. Багато пацієнтів продовжували застосовувати судинозвужувальні засоби, не знижуючи далі концентрацію діючої речовини. Враховуючи те, що цитологічне дослідження слизу з порожнини носа у пацієнтів, яких ми спостерігали, виявляло ознаки запалення (збільшення кількості нейтрофілів, еозинофілів, групи клітин циліндричного епітелію), ми рекомендували додавати до терапії інтраназальне застосування топічних кортикостероїдів.

Мета дослідження: дослідити ефективність застосування інтраназальних топічних кортикостероїдів у лікуванні пацієнтів із медикаментозним ринітом.

\section{Об'єкт і методи дослідження}

Досліджувану групу становили 20 пацієнтів із медикаментозним ринітом (16 чоловіків та 4 жінки віком 20-45 років). Тривалість захворювання становила до 2 років. Пацієнтам цієї групи призначено мометазону фуроат у формі інтраназального спрею по 2 дози (100 мкг) у кожен носовий хід 1 раз на добу вранці. Для полегшення носового дихання пацієнти цієї групи продовжували застосовувати звичайні деконгестанти, які, за їх твердженнями, їм найбільше допомагають. Єдиною умовою було розведення деконгестанту 50\% стерильним ізотонічним розчином натрію хлориду через кожні 4 дні.

Контрольна група пацієнтів становила 16 осіб (13 чоловіків і 3 жінки віком 20-50 років) із медикаментозним ринітом протягом не більше 2 років. Пацієнти цієї групи також використовували аналогічний метод розведення деконгестанту, але топічний кортикостероїд не застосовували.

Обираючи для нашого дослідження спрей, що містить мометазон, ми зупинилися на препараті Флікс як такому, що найбіль-

\section{Відомості про автора:}

Меркулов Олександр Юрійович — доцент кафедри отоларингології та дитячої отоларингології Харківської медичної академії післядипломної освіти, Харків, Україна.

Адреса для кореспонденції:

Меркулов Олександр Юрійович

61176, Харків, вул. Амосова, 58 ше відповідає вимогам нашого дослідження з точки зору оптимальної кількості доз і економічної обґрунтованості.

\section{Результати та їх обговорення}

За результатами проведеного дослідження 14 пацієнтів контрольної групи відзначали неефективність застосовуваних деконгестантів вже при 2-му, 2 пацієнти - при 3-му розведенні. В основній групі тільки 2 пацієнти відзначали неефективність при 2-му розведенні, 14 - при 3-му і 4 - стверджували, що після 3-го розведення у них зберігався ефект від деконгестанту, але менш виражений.

\section{Висновок}

Застосування топічних назальних кортикостероїдів у лікуванні медикаментозного риніту дозволяє суттєво знизити дозу деконгестантів, що застосовуються, або навіть повністю відмовитися від них.

\section{Список використаної літератури}

1. Hünerman T. (1942) Kritisches zur Schnupfentherapie. Deutsche MedizinischeWochenschrift., 68: 580-581. doi:10.1055/s-0028-1120135.

2. Gollom J. (1944) The problem of nasal medication with particular reference to Privine HCL $0.1 \%$. Can. Med. Assoc. J., 51(2): 123-126.

3. Riechelmann H., Deutschle T., Stuhlmiller A. et al. (2004) Nasal toxicity of benzalkonium chloride. Am. J. Rhinol., 18(5): 291-299.

4. Graf P., Hallen H. (1996) Effect on the nasal mucosa of long-term treatment with oxymetazoline, benzalkonium chloride, and placebo nasal sprays. Laryngoscope, 106 (5 Pt. 1): 605-609.

\section{Topical nasal corticosteroids in the complex treatment of drug rhinitis}

\section{O.Yu. Merkulov}

Kharkiv Medical Academy of Postgraduate Education, Kharkiv, Ukraine

Abstract. Patients suffering from drug-induced rhinitis often continue to use vasoconstrictive nasal drugs to eliminate nasal congestion before seeking medical attention, thus exacerbating the course of the disease. Objective: to investigate the effectiveness of intranasal topical corticosteroids in the treatment of patients with druginduced rhinitis. Object and methods of research. The study group consisted of 20 patients who suffered from drug-induced rhinitis for up to 2 years. Patients in this group were prescribed mometasone furoate intranasal spray 2 doses $(100 \mathrm{mcg}$ ) in each nasal passage once a day in the morning. To facilitate nasal breathing, patients continued to use decongestants diluted in $50 \%$ sterile isotonic sodium chloride solution every 4 days. A control group of patients ( 16 people with drug-induced rhinitis for no more than 2 years) used a similar method of diluting the decongestant, but did not use a topical corticosteroid. Results. 14 patients of the control group noted the ineffectiveness of the decongestants used on the 2 nd, 2 patients - on the 3rd dilution. In the main group, only 2 patients reported ineffectiveness on the 2 nd dilution, 14 - on the $3 \mathrm{rd}$ and 4 - claimed that after the 3rd dilution they retained the effect of the decongestant, but less pronounced. Conclusion. The use of topical nasal corticosteroids in the treatment of drug-induced rhinitis can significantly reduce the dose of decongestants, or even completely abandon them.

Key words: drug rhinitis, nasal vasoconstrictors, decongestants, naphazoline, topical nasal corticosteroids, mometasone furoate.

\section{Information about the author:}

Merkulov Olexandr Yu. - Associate Professor of Otolaryngology and Pediatric Otolaryngology, Kharkiv Medical Academy of Postgraduate Education, Kharkiv, Ukraine.

Address for correspondence:

Olexandr Merkulov

61176, Kharkiv, Amosov str., 58 